\title{
INFLUENCE OF SERVICE QUALITY ON PASSENGER SATISFACTION AT HALIM PERDANAKUSUMA AIRPORT, JAKARTA, INDONESIA
}

\author{
Cecep Ruhiyat ${ }^{1}$, Sandriana Marina ${ }^{2}$, Hanifah $^{3}$, Olfebri ${ }^{4}$ \\ 1.STMT Trisakti, 2.STMT Trisakti, 3.STMT Trisakti, 4. STMT Trisakti \\ $\triangle$ corresponding author: cecepruhiyat84@gmail.com
}

\begin{abstract}
Passengers' satisfaction of service quality at airports are becoming increasingly important as air traffic grows. This research investigated passengers' perceptions of satisfaction at Halim Perdanakusuma International Airport, Jakarta, Indonesia.This study aims to find alternative solution models through exploring and analyzing the data and information concerning the influence of service quality on customer satisfaction. The method in this research is descriptive and verificative with data analysis using simple linear regression. This study sample of 100 respondents, with simple random sampling method with the entire population of passengers in Halim Perdanakusuma International Airport, Jakarta. Using SPSS 24 version, the analize find that all instruments validand reliable.The research shows that service quality has influence positive significant through customer satisfaction. This study has some limitations so that further research can be carried out to develop the research model. The result of this research suggests to expand the study on its analysis unit in order to give wider contributions to studying customer satisfaction especially for passenger satisfaction in airport.
\end{abstract}

Keywords: Service Quality, Passenger Satisfaction, Halim Perdanakusuma Airport

\section{Introduction}

In the era of globalization and technology are already very advanced and develop, then, the transportation sector holds a vital role because it makes it easy to reach out to the community in a place for a particular purpose. In tune with it, with the prospects of the business, transportation it becomes very important for an individual or business organization to support all its activities to reach a region or a particular place with a relatively short time - and one of the service who had a major role in the development of the transport is flight service because it is considered capable of giving more time (Haryono et al., 2016). Accessibility is the main function behind the basics of tourism transport. In order to access the areas that are mainly aimed, tourists will use any transportation mode. However, air transport is the main mode for international 
tourism. Air transport plays a dominant role in inter-regional movements of tourists, which normally entails travel over long-distance (Ricardianto et al., 2017).

If the services received or perceived (perceived service) in accordance with the quality of service expected, yan are perceived good and satisfactory, sake that will impact raises the level of consumer loyalty (Saribanon et al., 2016). A quality service as well as the value of the services is high and important thing to build customer satisfaction in the service industry (Gilbert \& Wong, 2003), (Bitner, M. J., \& Zeithaml, 2003), (Kandampully, 2003). Due to the cognitive process, the service quality perceived is not only subjective, but also varies depending on the context and the possibility of some factors (Wilson et al., 2012). Passenger behaviour and expectations of the experience at the airport, depending on the type of tourists, travel destinations and other context with related aspects (Fodness \& Murray, 2007). Thus, attributes to measure the quality of service the airport should reflect evaluation with regard to the problem and investigating the environmental services (Bezerra \& Gomes, 2015),(Yeh and Kuo, 2003).

Halim Perdanakusuma international airport, located in Jakarta has also been made into a commercial airport (since 10 January 2014) in order to divert flights from Soekarno-Hatta that have been bursting at the seams (Andri et al., 2016). As a type B airport has the capacity to accommodate the number of passengers from 500 up to 1000 people per day(SKEP/2765/XII/2010, n.d.), HalimPerdanakusuma currently has served passengers of more than 1000 people per day. These conditions are like two sides of the coin. On the one hand, highly profitable passenger growth in the economy but on the other hand would be the disappointment of users services if the service does not match the given expectation.

Airport Operations Service Unit is spearheading the Airport Operations which in addition to its function, there are also weaknesses that in addition to 
the facilities and coordination problems, as well as human resources are less reliable and professional in his field ( Resky \& Simarmata, 2014). Several researchers have examined the factors of satisfaction or dissatisfaction of travelers against air transport industry(Mikulić \& Prebežac, 2011), (Sulzmaier, 2001). Given that " tourism service quality starts at the airport "(Rendeiro Martín-Cejas, 2006), this research focuses on the basic service of the airport and the results will contribute to the theoretical and practical importance for the field of transport and tourism.

\section{Method}

This research examines the deeper research variables are examined, i.e. service quality and passenger satisfaction, then the research was descriptive in nature. This research is focused on the attributes that are associated with the passengers who use the services of HalimPerdanakusuma International Airport. In the first phase of data analysis, the analysis of the factors underlying the extracted exploration dimensions of service quality as perceived by passengers.

A population is the collection of all elements include; gender, age, occupation, education, and travel destinations. The unit of observation in this study are passengers who were in the boarding lounge for the departure of Citilink and Batik Air at 12:35 - 13:45 with flight number QG 9321 destination Yogyakarta (JOG) departure time at 14:05 and ID 7515 purpose Surabaya (SUB) departure time at 14:05. Cross section data acquired in a single day on 02 November 2017.The sampling method used is sampling probability with simple random sampling technique in which all the elements of the population have an equal chance to be selected as a member of the sample. Members of the sample were selected randomly. Determination of the sample for the study of descriptive is $10 \%$ of the population, for corelational research at least 30 elements of the population, research is causal comparison at least 30 elements 
per group, and for experimental research is 15 elements per group (LR. Gay and P.L. Diehl, 1992)

Variable measurement research, namely; the independent variable (quality of service) and a dependent variable (satisfaction of passengers) performed with the dissemination of the questionnaire. The attitude of respondents towards questions asked using 5 (five) measurement scale with ordinal data types. All variables will be measured by likert scale model, where 1 is very bad for the assessment or strongly disagree, and the number 5 for the assessment of very good or very much agree.

\section{Discussion and Result}

Validity of the test used to measure whether legitimate or grain of the questionnaire. The formula that is used to test the validity of the instrument is the Product Moment from Karl Pearson by using SPSS Statistics software 24 version with a sample of twenty. Test the validity of the calculation results for all statements indicate valid because the value of r-count greater than r-tables $(0.4438)$

While the reliability test done to get the level of precision, data-collecting instruments used(Riduwan and Kuncoro, 2011). Reliability test done with a cronbach alpha formula. Same is the case with test validity, reliability test on this research was conducted with of SPSS Statistics software24 version too. Reliability test results of the variable quality of service showed a Cronbach Alpha coefficient value of $0.941 \geq 0.7$ and Cronbach Alpha coefficient variable value competitive advantage of $0.869 \geq 0.7$. This means that all variables and dimensions are realible. This indicates that all the instruments can be used in this study.

Simple regression coefficient calculation results by using SPSS software 24 version shows the value of constant coefficient, the coefficient of the variable $\mathrm{X} 0.118$ (quality of service) amounted to 1.452 regression equation model is obtained so that $\mathrm{Y}=1.452+0,118 \mathrm{X}$. The value of the constant is 
1.452, meaning if the service quality $(\mathrm{X})$ value is 0 , then the passenger satisfaction (Y) value is positive.Coefficient regression 0.118 of a variable quality of service amounted to 1.452 meaning if the quality of service experienced a rise in 1 , then the satisfaction of passengers will experience an increase of 0.118 . The coefficient is positive, it means going on a positive relationship between passenger satisfaction with quality of service, the quality of service is increasing then increasing passenger satisfaction.

The value of the correlation coefficient $(\mathrm{R})$ was 0.691 interpreted that the relationship of these two variables the study exist in the category of "strong". Cooefisien determination value (R Square) amounted to $47.8 \%$ which can be interpreted that the quality of service has influence the contribution amounted to $47.8 \%$ against the satisfaction of passengers. The rest of $52.2 \%$ influenced other factors outside of the variable quality of service.

Significance test used to determine the extent of the significance or linieritas of regression. The criteria can be determined based on the value of significance tests ( $\mathrm{Sig}$ ), provided if the value is $\mathrm{Sig}<0.05$. Based on statistical calculation, obtained the value of Sig. $=0.001$ means Sig. significant criteria of $<(0.05)$. Thus the model regression equation based on research data was significant, or regression equation model meets the criteria.

From the results of the calculation of the tcalculate of 4.056 compared to ttabel of 1.98447 a $5 \%$ significance level, then tcalculate $>\mathrm{t}$ table, thus it was concluded that the variable quality of service significantly to influential variable satisfaction passengers.

This research proves that the quality of service to the satisfaction of passengers. That is, the model of research that was formed from the results of the study of literature and previous research is in accordance with the results of this research. To increase passenger satisfaction at Halim Perdanakusuma, can be done by improving the quality of service so that it can be used as a basis or reference in corporate decision making. 


\section{Conclusion}

In overall models above show that service quality is the factor that will make up the satisfaction of passengers. The higher the quality of service perceived by passengers, the higher the satisfaction that will be felt by passengers. The research results prove positively influential service quality significantly to the satisfaction of the passengers at the international airport of HalimPerdanakusuma in Jakarta. This research is the development of the theory (Fodness \& Murray, 2007)where a passenger's behaviour and expectations of the experience at the airport, depending on the type of tourists, travel destinations and other aspects of the context associated with it. This is evidenced by the presence of the influence of the quality of service to the satisfaction of the passengers at HalimPerdanakusuma International Airport, Jakarta.

\section{References}

Bezerra, G. C. L., \& Gomes, C. F. (2015). The effects of service quality dimensions and passenger characteristics on passenger's overall satisfaction with an airport. Journal of Air Transport Management, 44-45, 77-81. https://doi.org/10.1016/j.jairtraman.2015.03.001

Bitner, M. J., \& Zeithaml, V. A. (2003). Service Marketing. TataMcGraw Hill, New Delhi.

Fodness, D., \& Murray, B. (2007). Passengers' expectations of airport service quality. Journal of Services Marketing, 21(7), 492-506. https://doi.org/10.1108/08876040710824852

Gilbert, D., \& Wong, R. K. C. (2003). Passenger expectations and airline services: A Hong Kong based study. Tourism Management, 24(5), 519532. https://doi.org/10.1016/S0261-5177(03)00002-5

Mikulić, J., \& Prebežac, D. (2011). What drives passenger loyalty to traditional and low-cost airlines? A formative partial least squares approach. Journal of Air Transport Management, 17(4), 237-240. https://doi.org/10.1016/j.jairtraman.2010.09.005

Rendeiro Martín-Cejas, R. (2006). Tourism service quality begins at the airport. Tourism Management, 27(5), 874-877. https://doi.org/10.1016/j.tourman.2005.05.005

Riduwan and Kuncoro. (2011). Cara menggunakan dan memakai path analysis (analisis jalur). Bandung: Alfabet. 
SKEP/2765/XII/2010. Kementerian Perhubungan Republik Indonesia.

Sulzmaier, S. (2001). Consumer-oriented Business Design: The Case of Airport Management. Physica-Verlag HD, New York, NY.

http://library.stmt-trisakti.ac.id/jurnal/index.php/JMBTL/article/view/47 http://ejournal.stmt-trisakti.ac.id/index.php/jmtranslog/article/view/81/36 http://ejournal.stmt-trisakti.ac.id/index.php/jmtranslog/article/view/143/101 http://www.iosrjournals.org/iosr-jac/papers/vol10-issue5/Version1/A1005010119.pdf

http://library.stmt-trisakti.ac.id/jurnal/index.php/JMBTL/article/view/4 